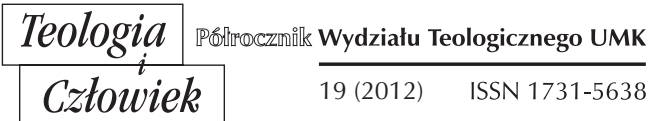

\title{
INTELEKTUALIZM ETYCZNY W STAROPOLSKIEJ MYŚLI MORALNEJ
}

Nieco bliższy wgląd w dorobek rodzimej myśli etycznej XVI i XVII wieku ujawnia bogactwo tematyki podejmowanej przez myślicieli i pisarzy owych czasów. Filozofię moralną pojmowano wówczas bardzo szeroko, włączając w jej obszar nie tylko refleksję skupioną na analizie ideału etycznego, konstruowaniu i uzasadnianiu określonej hierarchii wartości, katalogu cnót, czy etyce życia indywidualnego, ale także problematyki etyki społecznej, etyki życia politycznego, gospodarczego i wychowania moralnego. Filozofią panującą wówczas na uczelniach europejskich oraz w szkolnictwie polskim był w dalszym ciągu arystotelizm. Uprawiany był metodą komentowania, wnikliwego drążenia problemów. Nie zajmował on jednak pozycji monopolistycznych, bowiem w wyjaśnianiu i uzasadnianiu różnych kwestii i propozycji etycznych chętnie sięgano także do myśli Sokratesa, Platona, Seneki, Marka Aureliusza czy Cycerona. Żywe w myśli staropolskiej - może nie zawsze dostatecznie akcentowane w opracowaniach - były wpływy etycznej tradycji sokratejsko-platońskiej,

* Włodzimierz Tyburski - prof. zw. dr hab., filozof i etyk, kierownik Katedry Filozofii Moralnej i Bioetyki w Instytucie Filozofii UMK, członek Komitetu Nauk Filozoficznych, członek Centralnej Komisji do Spraw Tytułu Naukowego i Stopni Naukowych. 
szczególnie wyraziście uwidaczniające się w znaczeniu, jakie pisarstwo interesujące nas epoki przypisywało dobrze znanemu w etyce stanowisku określanego mianem intelektualizmu etycznego. Nie zawsze pojawia się ono w swej ścisłej, rzec można, kanonicznej postaci, często jest w różny sposób interpretowane i modyfikowane.

Już wśród pisarzy XV stulecia znajdujemy nawiązania do idei intelektualizmu etycznego. Pierwszy rektor Akademii Krakowskiej Stanisław ze Skarbimierza (zm. ok. 1431 r.) w traktacie teologicznym Determinatio oraz w kazaniach i mowach uniwersyteckich ujawniał kwestie dotyczące relacji wiedzy i moralności, najwybitniejszy zaś przedstawiciel myśli etycznej tego stulecia Paweł z Worczyna (ok. 1380-1430) dowodził, że człowiek nie może dostatecznie rozwijać cnót bez mądrości i roztropności, że wiedza pobudza i zbliża nas nieporównanie bardziej do dobra aniżeli do zła. Dochodził do wniosku, że „nie można być dobrym pod względem moralnym bez mądrości, lecz i przeciwnie nie można być mądrym bez tego, by być dobrym moralnie"1. Także nawiązujący do myśli Dunsa Szkota profesor filozofii Akademii Krakowskiej Jan ze Stobnicy (ok. 1470-1519) wskazywał na sojusz rozumu i cnoty i wysoko cenił roztropność jako cnotę intelektualną, gdyż najbardziej jest ona pomocna przy wydawaniu prawidłowych ocen dotyczących etycznych aspektów życia indywidualnego i społecznego. Na zagadnienie związku wiedzy i moralności, mądrości i cnoty zwracał uwagę profesor wydziału filozoficznego Akademii Krakowskiej Szymon Maryciusz z Pilzna (1516-1574) autor głośnego dzieła O szkołach czyli akademiach, także Jan ze Trzciany 1510-1567) autor rozprawy O godności $i$ naturze człowieka. W nawiązaniu do sokratejskiej tradycji dowodził, że sensowne bytowanie w świecie zaczynać należy od poznania dobra i rozumnego, aktywnego kształtowania samego siebie, gdyż ono dopiero przygotowuje człowieka do bycia wśród innych i działania dla dobra innych. Z kolei Wojciech Nowopolczyk (1508-1559) dowodził, że „umysł ma w człowieku największe znaczenie”"2, kto zatem „kieruje się wskazaniami umysłu, ten najlepiej korzysta z życia”3. Sądził, że wiedza

${ }^{1}$ J. B. Korolec, Filozofia moralna. Dzieje filozofii średniowiecznej w Polsce, t. VII, Wrocław 1980, s. 140.

${ }^{2}$ W. Nowopolczyk, Oratione lauda physices (Mowa pochwalna na cześć fizyki), Kraków 1551, w: Filozofia i myśl społeczna XVI wieku, red. L. Szczucki, ser. „700 lat myśli polskiej", Warszawa 1978, s. 143.

3 Tamże, s. 150. 
o świecie natury i o człowieku nie tylko zaspokaja potrzeby poznawcze ale także go umoralnia i mobilizuje do doskonalącej pracy nad sobą.

Najwybitniejszy przedstawiciel rodzimej myśli społeczno-politycznej epoki odrodzenia Andrzej Frycz Modrzewski (ok. 1503-1572) uważał, że punktem wyjścia do naprawy obyczajów jest racjonalne rozpoznanie dobra. „Przy tym obstaję - powiada pisarz - że wielu (występków WT) ludzie dopuszczają się, ponieważ nie wiedzą co jest dobre $^{\prime 4}$. W tworzeniu dobra wiedza etyczna spełnia propedeutyczna, ale zarazem doniosłą rolę, następnie uwzględnić należy nasze przyzwyczajenia, gdyż wielu popełnia rzeczy niegodziwe właśnie z przyzwyczajenia do złego, tak jak inni czynią to, co uczciwe z przyzwyczajenia do tego, co uczciwe. Dobre obyczaje, czyli sfera moralności, opierają się - powiada Modrzewski - na rozumie i przyzwyczajeniu. W tym sposobie myślenia pojawia się sokratejski wątek. Zło wynika z niewiedzy i przyzwyczajenia do zła. Ale także pojawia się realna możliwość rozpoznania dobra, nabycia wiedzy etycznej i w dalszej kolejności wyrobienia w sobie przyzwyczajenia do dobra. Naczelnym więc zadaniem rozumu jest poznanie tego „co jedynie dobre”. W samym zaś procesie poznawania chodzi o to, aby nic nie uronić z "owych iskier cnoty i mądrości” w nas tkwiących, lecz poprzez nieustanne ćwiczenia i doskonalenie „rozbudzać $\mathrm{w}$ gorejące płomienie" ${ }^{\prime \prime}$.

Wszelkie zło indywidualne i społeczne ma swoje źródło przede wszystkim w "niewiedzy” o tym, co dobre. Niewiedza jest bowiem postacią ślepoty na to, co wartościowe i cenne w życiu człowieka. „Pierwszą tedy i najważniejsza troską każdego być winno, aby rzecz każdą dobrze pojąć i o niej sądzić, jak można najtrafniej”6. Samo poznanie dobra jest niezbędnym, ale jeszcze niewystarczającym warunkiem moralnego postępowania. Nasze działania i czyny nie są prostą wypadkową poznania. W wydatny sposób wpływają na nie także nasze namiętności, pragnienia, pożądania. I to one właśnie sprawiają, iż mimo świadomości dobra, wybieramy niekiedy jego przeciwieństwo. Jakże często między rozumem a namiętnościami dochodzi do ostrego konfliktu. I bywa, że to nie głos rozumu, lecz namiętności biorą górę. Trafnie ów antagonizm rozumu i namiętności uchwycił Owidiusz, gdy w jednym ze swoich utworów

4 A. Frycz-Modrzewski, O poprawie Rzeczypospolitej, fragm, w: Filozofia i myśl społeczna XVI wieku, s. 251.

5 Tamże.

6 Tamże, s. 252. 
powiedział: "co lepsze widzę i pochwalam, lecz idę za tym, co gorsze"7. Dlatego - podkreśla Modrzewski - nie wystarcza, aby rozum rozpoznał sferę dobra, ważne jest również, aby zapanował nad pożądaniami i namiętnościami. Może to uczynić dzięki posiadanej wewnętrznej sile, jaką jest wola. Do niej - powiada pisarz - należy odwoływać się „Wzmacniać, kiełznając, opanowując i powstrzymując afekty, ażeby tyle miała sił do działania, ile za potrzebne uzna sam rozum"s. Czyn etyczny jest zatem wypadkową świadomości dobra i wiedzy o tym, jak postępować, do których dołącza się „pilność i przyzwyczajenie czynienia tego, co należy" ${ }^{\prime \prime}$. To, co pisarz nazywa "stanem moralnej dzielności” jest owocem umiejętności wyboru właściwego środka między nadmiarem i niedomiarem. Rozum pozwala odróżnić dobro od zła, wola wybiera dobro, starając się unikać zła, zaś nawyk przyzwyczaja, utrwala człowieka w działaniu cnotliwym.

W kontekst interesującej nas tematyki wpisują się także niektóre poglądy Wawrzyńca Goślickiego (ok. 1530-1607) - dyplomaty, pisarza politycznego i sekretarza królewskiego. Myśl filozoficzno-polityczna Goślickiego nawiązuje do Arystotelesa, ale wyraźnie zaznaczają się w niej ślady poglądów min. Sokratesa i Platona. Widoczne jest to w wyeksponowaniu przez uczonego cnoty roztropności, a właściwie ulokowaniu jej na pierwszym miejscu w hierarchii cnót. Roztropność polega na intelektualnym rozpoznaniu dobra i rozumnym wyborze właściwego postępowania. Doniosłość tej cnoty potwierdza się i sprawdza w przynoszących pożytek czynach i działaniach. Cnotami posiłkującymi roztropność są: uzdolnienia, pojętność, pamięć, bystrość, rozwaga oraz umiejętność przewidywania. Doniosłość tej ostatniej Goślicki mocno akcentuje. Tak rozumiana roztropność jest w ścisły związku ze sprawiedliwością, gdyż wydatnie wspomaga formułowanie sądów sprawiedliwych i działań w duchu sprawiedliwości, które wymagają - jak powiada Goślicki - oddania każdemu tego, co mu się należy.

Duch intelektualizmu etycznego ujawnia się także w refleksji Łukasza Górnickiego (1527-1603) wybitnego humanisty i pisarza, świetnie wykształconego prawnika i historyka. Wskazywał na potrzebę ścisłego sojuszu wiedzy i etyki, mądrości i cnotliwości. To rozum - powiada Górnicki - jest źródłem wiadomości o dobru, cnotach i powinnościach.

\footnotetext{
7 Tamże.

8 Tamże, s. 254.

9 Tamże.
} 
Człowiek myślący prawidłowo wie, czym jest dobro. Nie może więc mieć fałszywych wyobrażeń moralnych, dysponując wiedzą na temat dobra i zła. Dzięki tej wiedzy wybieramy właściwą drogę postępowania. Myśl powyższą autor Dworzanina polskiego rozszerza w takiej oto wypowiedzi, „bo gdzieżby człowiek, co dobre, a co złe, gruntownie znał, każdy by wolał obrać to, co dobre, niż to, co złe,. Przeto cnotę, kto by chciał wyłożyć, co jest w sobie, mógłby ją nazwać mądrością, iż ona wie, rozumie i umie obrać to, co jest dobre, a niecnotę zasię mógłby nazwać głupstwem a nieumiejętnością, która oszukiwa człowieka, a złe za to dobre pokazuje, bo nigdy ludzie nie obierają złego tą myślą, aby złe było, ale się prawdopodobieństwem omylaja, mając to za dobre, co się nieczem nie godzi"10.

$\mathrm{W}$ wypowiedzi tej mamy do czynienia z iście sokratejską apoteozą rozumu, $\mathrm{z}$ podkreślaniem jego mocy sprawczej w dziele moralnego doskonalenia człowieka. Przekonaniu o związku rozumności z dobrem towarzyszył pogląd, że zło w istocie jest dzieckiem głupoty, że - jak powiadał Górnicki - „wszelka złość z głupstwa pochodzi”. Z kolei arystotelesowski motyw wyraźnie pobrzmiewa w głoszonym przez Górnickiego przekonaniu, że doskonałość moralna polega na zachowaniu zasady umiaru. „Cnota - powie pisarz w duchu autora Etyki nikomachejskiej - pośrodku mieszka nie przechodząc zamierzonego kresu ani ku wielkości, ani ku małości"11. Znalezienie właściwej miary jest zatem warunkiem niezbędnym postępowania moralnego i racjonalnego zarazem. Cnota zaś jest swego rodzaju sprawnością wskazującą rozwiązania pośrednie, lokujące się między skrajnościami. Cnota zabezpiecza prawdziwą wartość czynu, gdyż „co nie ma miary w sobie, ale gwałtownie idzie, to trwać nie może $\mathrm{e}^{\prime 12}$. Każde zatem postępowanie jest wadliwe, jeśli charakteryzuje się nadmiarem lub niedomiarem. „Miary we wszystkich potrzeba rzeczach” - nawołuje autor Dworzanina i zarazem dodaje - to, co "najpiękniejsze” $\mathrm{i}$ „najpożyteczniejsze” ${ }^{\prime 13}$ jest w działaniu umiarkowanym, rozwiązaniach pośrednich. To zaś, co "najsprośniejsze” - to wynik skrajnych, a więc nierozumnych rozwiązań i wyborów. Każda rzecz, „która pośródek przejdzie w wielkością swoją sobie jest ciężka, dobrą być nie może"14.

\footnotetext{
${ }^{10}$ Ł. Górnicki, Dworzanin polski, oprac. S. Łempicki, Warszawa 1958, s. 278.

${ }^{11}$ Tenże, O elekcji, wolności, prawie i obyczajach polskich. Rozmowa Polaka z Włochem,

${ }^{12}$ Tamże, s. 15

${ }^{13}$ Tamże.

${ }^{14}$ Tamże, s. 16-17.
} Sanok 1855, s. 16. 
Zatem także w wyborach zdążających do umiaru i wytyczania środka między skrajnościami niezbędny jest rozumu, sama zaś umiejętność właściwego wyboru - przejawem mądrości.

Sokratejskiej proweniencji intelektualizm etyczny i arystotelesowska idea „właściwej miary”, wzbogacone o nastawienia eudajmonistyczne miały uzasadniać przekonanie, że „cnoty czynią człowieka szczęśliwego"15.

$\mathrm{Na}$ drugą połowę XVI wieku datuje się powstanie i rozwój filozoficzno-teologicznej myśli polskiego antytrynitaryzmu. Z punktu widzenia tytułowej tematyki na szczególną uwagę zasługują poglądy jednego liderów tego nurtu Szymona Budnego (ok. 1530-1593). Myśl teologiczna Budnego wyróżniała się w piśmiennictwie antytrynitarskim odmiennym ujęciem niektórych kwestii chrystologicznych, zwłaszcza zaś śmiałymi interpretacjami wybranych tekstów Nowego Testamentu. Poglądy etyczne przedstawił Budny głównie w Komentarzach do Apophtogmatów. Uważał, że etyka chrześcijańska winna w szerszym zakresie czerpać z myśli klasyków, nawiązując zwłaszcza do tych ogólnoludzkich wartości, które wypracowała myśl etyczna antyku. Pojawia się tu także myśl o możliwej niezależności etyki od religii oraz - co zbliża Budnego ku sokratejskiemu postulatowi - oparcia etyki na rozumie i wiedzy. $\mathrm{Z}$ kolei duch arystotelizmu ujawnia się w wypowiedzi Budnego na temat możliwości osiągnięcia cnót moralnych. Uważał on, że cnoty człowiek rozwija przede wszystkim w procesie poznania i działania. Zalecał nieustanne ćwiczenie i doskonalenie się w życiu cnotliwym, ponieważ „christianin ma być pokorny, cichy, spokojny, miłosierny; nie ma się swej krzywdy mścić, ale cierpliwym być i krzyż (gdy Bóg nań kładzie ) winien nosić"16. Do cnót chrześcijańskich dodawał niektóre zalety sokratejskie i stoickie, takie jak: rozumność, panowanie rozumu nad uczuciami, wolna wola. Wskazywał na rolę i znaczenie opartej na myśleniu racjonalnym filozofii w budowaniu moralnej autonomii człowieka. Podkreślał, że dzięki wiedzy filozoficznej może on lepiej rozpoznawać dobro i zło, łatwiej podejmować samodzielne, trafne wybory moralne.

Jedną z najbardziej wybijających się postaci polskiego życia intelektualnego przełomu XVI i XVII wieku był Sebastian Petrycy z Pilzna (1554-1620). Wyjątkowe miejsce w historii rodzimej myśli filozoficzno-społecznej i etycznej wyznaczone zostało przez dzieło

${ }^{15}$ Tamże, s. 103.

${ }^{16}$ Szymon Budny, O urzędzie miecza używającym, Łosk 1583, w: Filozofia i myśl spoteczna XVI wieku..., s. 371. 
jego życia, jakim był przekład Etyki, Ekonomiki i Polityki Arystotelesa, zaopatrzony imponującym swoimi rozmiarami i walorami materiałem komentatorskim. Cel, jaki przyświecał uczonemu przy podjęciu tego pionierskiego zadania był raczej skromny. Udostępniając czytelnikowi polskiemu filozofię praktyczną Arystotelesa pragnął ją spopularyzować i - jak powiadał - uczynić pospolitą. Swoim dziełem wpisał się do grona najwybitniejszych arystotelików swoich czasów. Było to w istocie wielkie dokonanie, kładące podwaliny - jak zauważa Zbigniew Ogonowski - „pod rozwój polskiej terminologii filozoficznej”17. Nie mniej ważny niż sam przekład jest bardzo bogaty i wartościowy dorobek komentatorski uczonego. Zawarty jest w trzech obszernych dziełach pt. Przestrogi, Przydatki, Dokłady. Podstawą przedstawianych tam poglądów był oczywiście arystotelizm, na zaś plan pierwszy wszelkich dociekań wysuwała się problematyka etyczna. Przy czym intelektualizm był jedną z najbardziej wyrazistych cech etyki Petrycego. Rozum - uważał myśliciel - jest główną władzą duszy i dzięki niemu można ogarnąć, objaśnić i opracować bogatą dziedzinę zagadnień etycznych. On ukazuje nam etyczny wymiar czynu, przybliża nas do definicji dobra i zła, pozwala lepiej zrozumieć czym jest cnota i najwyższe szczęście. Bez odwołania się do możliwości, jakimi on dysponuje, trudno w istocie sensownie poruszać się w świecie etyki. "Rozum - powiada Petrycy - jest królem i rządcą wszystkich spraw naszych i dusznych władzy", zatem "dobre życie na rozumie, najprzedniejszej części człowieka zależy"18.

Intelektualistycznego wymiaru nabiera również zagadnienie szczęścia najwyższego, gdyż właśnie „na umyśle najwięcej szczęście ludzkie zawisło”. Także "wszystkie cnoty i obyczaje dobre od rozumu, jako z jakiego źródła pochodzą i rozumowi dworzą" [...]. "Albowiem tak dalece jest cnota, jak dalece $z$ dobrego rozumu pochodzi". Jest zatem tak, że "cnoty wszystkie przynależą do myśli, jako pana i księcia". Również wszelkie "żądze zmysłowe mają ten urząd i tę powinność słuchać rozumu, tak mają być uskromione i nałogiem okiełznane, aby rady słuchali rozumu jako konie woźnice" ${ }^{\prime 19}$. Rozum stanowi także podstawę powinności etycznej i wyznacza drogę do najwyższego szczęścia.

${ }^{17}$ Zarys dziejów filozofii w Polsce. Wiek XIII-XVII, red. Z. Ogonowski, Warszawa 1989, s. 415.

${ }^{18}$ S. Petrycy z Pilzna, Przydatki do Polityki Arystotelesowej, w: Pisma wybrane, t. I, Warszawa 1956, s. 317.

${ }^{19}$ S. Petrycy z Pilzna, Przydatki do Etyki Arystotelesowej, w: Pisma wybrane, t. I, Warszawa, 1956, s. 26. 
Rozważania na temat roli rozumu w postępowaniu etycznym konkluduje Petrycy następującym zdaniu: „człowiek prawdziwy duszą rozumną jest" ${ }^{\prime 20}$.

Stanowisko intelektualizmu etycznego wiąże etykę Petrycego z tradycją sokratyczno-platońską. $Z$ kolei zagadnienie woli jest bezpośrednim nawiązaniem do poglądów arystotelesowskich. Wszakże i tu wskazuje się na znaczenie rozumu, ale jednocześnie podkreśla się, że wola i obyczaj jedynie swój początek bierze od rozumu, dalej rządzi się już swoimi prawami, gdyż bywa, że nieopanowany człowiek, choć ma dobre nawet rozeznanie $\mathrm{w}$ sprawach etycznych, to namiętności i żądze popychają go w innym kierunku, niż radzi rozum. Petrycy rozważał zagadnienie rozumu i woli w postępowaniu etycznym człowieka. Autor Przydatków stara się ukazać ułomność jednostronnych stanowisk i odwołując się do empirii życia, wskazuje na bogactwo form postępowania oraz ich uwarunkowań, gdzie prymat przypada raz rozumowi, innym razem namiętnościom i uczuciom, jeszcze innym razem okazuje się, że czyn stanowić może wypadkową obu uwarunkowań (rozumu i woli) albo zgoła jeszcze innych okoliczności. Sytuację tę Petrycy ilustruje następującą sekwencją myśli wypowiedzianych w pięknej staropolskiej stylistyce: człowiek, gdy „postępuje do czynienia czegoś, to czasem nie używa rozumu, ale jak zwierzęta nieme, bywa prowadzony pobudką natury, co widzimy w dzieciach i szalonych ludziach, którym, iż nie służy rada i wybór, nie może też służyć wolność używania. Drugi sposób jest, gdy człowiek używa rozumu, wszakże ten rozum jest skażony, a w ten sposób rozum zezwala na to, co się zda i podoba umysłowi; a tak zgadzają się skażony rozum, wola, wybór i żądza, jako widzimy to w uczynkach człowieka złośliwego. Trzeci sposób: może rozum być dobry, a z nim się zgadza żądza, wola i wybór, co widzim w dobrym i cnotliwym człowieku. Czwarty sposób: może rozum być dobry, ale żądza smysłów opiera się i odejmuje rozumowi, panuje i wolą zwycięża. Co widzimy ludziach niepohamowanych, którzy mówią: widzę, co lepsze, wszak udaję się za złym. Nawet może rozum być rozum i może panować nad wolą, acz żądza smysłów opiera się, co widziemy w człowieku niepohamowanym, w którym wola rządzi i zwycięża żądzą. We wszystkich czterech ostatnich sposobiech najduje się wolność, ile człowiek zawżdy jest swoich uczynków panem"21.

\footnotetext{
${ }^{20}$ Tamże.

${ }^{21}$ Tamże, s. 286-287.
} 
Intelektualizm w staropolskiej myśli etycznej często utożsamiany jest z kategorią roztropności. Wyraźnie widać to na przykładzie filozofii moralnej Tomasza Elżanowskiego (1590-1654) teologa i filozofa jezuickiego, którą to postać i dzieło przybliżył świadomości współczesnych R. Darowski ${ }^{22}$. W konwencji epoki lokują się poglądy etyczne Elżanowskiego, zwłaszcza gdy korzysta z Arystotelesa, za pośrednictwem jego komentatorów, zwłaszcza Tomasza z Akwinu. Jednak - jak podkreśla to Darowski - w przypadku problematyki etycznej owa zależność jest mniejsza niż w przypadku filozofii przyrody. Można wskazać na pewne odmienności, swoistość i nowe akcenty pojawiające się w myśli etycznej Elżanowskiego. Wprawdzie wiernie za Arystotelesem dzieli filozofię moralną na etykę, ekonomikę i politykę, ale do swej etyki wprowadza też nowy element poprzez przypisywanie szczególnego znaczenia kategorii roztropności. Etyka jest dla niego, i tu wierny pozostaje Stagirycie, przede wszystkim nauką o cnotach (aretologia). Ale w katalogu cnót bardzo wysoko lokuje roztropność, o której mówi, że jest właściwym sposobem działania w stosunku do tego, co jest dobre lub złe dla człowieka. Dobro dotyczy samego człowieka i innych osób i przejawiać się może w obszarze życia ekonomicznego i politycznego. Stąd wyróżnia Elżanowski roztropność moralną (osoby i inny innych ludzi), gospodarczą (domu-rodziny), obywatelską (polityki). Roztropność niezbędna jest we wszystkich obszarach życia i działania. Wydatnie udoskonala samego człowieka, jego stosunki z innymi ludźmi, jak i jego poczynania na polu ekonomiki i życia obywatelskiego.

Roztropność, pojmowaną jako podstawową cnotę etyczną, Elżanowski analizuje i rozpatruje $w$ dwóch zasadniczych płaszczyznach: teoretycznej i praktycznej. W ramach pierwszej dokonuje podstawowych podziałów, wyróżniając roztropność osobistą i kierowniczą. Te ostatnią zaś dzieli na ustawodawczą, administracyjną i ustawodawczą. Przyjmując, że roztropność jest nieodłączną cechą intelektu pokazuje, czym w istocie różni się ona od mądrości, nauki, opinii oraz sądu sumienia. Roztropność rozpatrywana z pozycji praktycznych poszukuje środków do osiągnięcia celu, wskazuje, jak godziwie ułożyć własne życie, stosunki z innymi ludźmi, a także jak właściwie postępować $\mathrm{w}$ sprawach dotyczących polityki i państwa.

${ }^{22}$ R. Darowski, Życie i działalność filozoficzna Tomasza Elżanowskiego (!590-1657), „Studia Philosophiae Christianae”, t. 15, 1979, nr 2. Na podstawie tego studium przedstawiamy wybrane poglądy etyczne Elżanowskiego, por. także R. Darowski, Studia z filozofii jezuitów w Polsce XVII i XVIII wieku, Kraków 1998, s. 101-133. 
Dzięki cnocie roztropności człowiek odnajduje bardziej skuteczne sposoby osiągnięcia celu ostatecznego, czyli dobra najwyższego, jakim jest pełne szczęście. Polega ono na zdobywaniu i praktykowaniu cnoty, nie zaś na posiadaniu bogactw, zaszczytów czy władzy. Elżanowski powiada, że cnota moralna jest „stałym nawykiem (skłonnością) zdolnym do dokonywania wyboru (electivus), polegającym na umiarze, który przystoi człowiekowi roztropnemu"23, pojawia się u tego, kto kierującego się zasadą roztropności. Rzec można, że roztropność jest cnotą i zarazem warunkiem cnót moralnych.

Cnotę roztropności wysoko cenił także Wojciech Tylkowski (1625-1695), którego twórczość zaliczyć należy do przodujących osiągnięć polskiej myśli teologicznej XVII wieku. Pośród rozlicznych zainteresowań wiele uwagi poświęcał filozofii moralnej i jej trzem zasadniczym działom: etyce, ekonomice i polityce. Etykę pojmował jako naukę o cnotach. Tylkowski wyróżnia i omawia cztery zasadnicze cnoty: roztropność, sprawiedliwość, męstwo i wstrzemięźliwość. Każda z wymienionych cnót ma tu swoją charakterystykę i wspomagana jest przez bardziej szczegółowe i podporządkowane im cnoty. Cnota roztropności związana jest w sposób najbardziej ścisły z rozumem. Charakteryzuje ją równowaga umysłu, zdolność do przewidywania przyszłości, zdawania sobie sprawy z możliwych konsekwencji naszych czynów, zachowań i działań. Dodatkowo roztropność uzupełniają takie cnoty małe jak: ostrożność, rada, przezorność, oględność. Wszystkie one związane są w mniejszym lub większym stopniu z intelektualną, rozumową aktywnością człowieka. Tylkowski uważał, że istotnym drogowskazem w poszukiwaniu prawdy moralnej może być dla nas intuicja moralna, ale jednocześnie zaraz dodawał i wyraźnie to podkreślał, że powinna być ona pojmowana jako zdolność intelektualnego rozpoznawania dobra i zła moralnego. Tak pojmowana intuicja nie jest dyspozycją trwałą. Tylkowski wyraża optymistyczne przekonanie, że realizowanie dobra jest w zasięgu możliwości człowieka. Prawość intelektualna zawsze jest sojusznikiem prawości moralnej i na odwrót. Osiągamy je poprzez ćwiczenia w cnotach, zaś sprawdzianem naszej wartości wewnętrznej są trudne doświadczenia życiowe. Dlatego nie należy uciekać od wszelkich przeciwności i trudności, gdyż one są prawdziwym weryfikatorem tego, co sobą reprezentujemy. Powodzenie życiowe, bogactwa materialne $\mathrm{w}$ istocie nie czynią nas lepszymi, $\mathrm{z}$ reguły wywierają na nas negatywny wpływ. Kto zatem pragnie być dobrym,

${ }^{23}$ Cyt. za: tamże, s. 60. 
musi z wielu przyjemności zrezygnować i koncentrować się na pomnażaniu dobra moralnego. Natura nasza daje nam możliwość wyboru i obdarza nas zdolnościami samostanowienia o naszym obliczu moralnym. Tylko od nas zależy, od naszej roztropności i mądrości, czy te zdolności wykorzystamy do powiększenia sumy dobra moralnego, czy też zła moralnego, które pojawia się tam, gdzie bark cnoty roztropności i mądrości. Od nas zależy, czy otrzymamy od Boga dar, jakim jest zdolność tworzenia wartości moralnych wykorzystamy w celu poszerzania obszaru dobra.

O cnocie roztropności pisał także jeden z najznakomitszych uczonych doby nowożytnej na terenie Gdańska Bartłomiej Keckermann (1572-1609) - reprezentanta myśli protestanckiej. Wszechstronność zainteresowań, daleko wykraczającą poza dyscypliny filozoficzne, kompetencje w zakresie nauk matematycznych i przyrodniczych pozwalają scharakteryzować tego myśliciela jako postać renesansowa, polihistoryczną.

Główne dzieło Keckermanna poświecone problematyce etycznej to Systema ethicae III libres (System etyki w trzech ksiegach) ${ }^{24}$, którego uzupełnieniem były Disputationes practicae (Dysputy praktyczne) ${ }^{25}$. Zdaniem Keckermanna etyka jako dziedzina wiedzy ma przede wszystkim na względzie dobro ogółu. Posiada ona „mądrość kierowania wolą i pożądaniem dla znalezienia dobra publicznego"26. We wstępnej części Systema ethicae Keckermann hierarchizuje wartości i cnót. Na pierwszym miejscu wymienia wartość szczęścia (szczęśliwości) i wyróżnia szczęśliwość absolutną i szczęśliwość etyczną. Zaraz w kolejności, w hierarchii cnót, lokuje Keckerman cnotę roztropności. W jej ramach wyróżnia roztropność etyczną i roztropność duchową. Pierwsza jest "kierowniczką cnót etycznych, politycznych i domowych [...], druga jest „kierowniczką cnót boskich, zwanych duchowymi"27. Dzięki roztropności człowiek potrafi oddzielić dobro o zła i przyjąć postawę umiarkowania wobec różnych okoliczności życia. Analogicznie do wymienionych podziałów wyróżnia cnoty duchowe i cnoty etyczne. Cnoty duchowe określa jako doskonałe, gdyż wiodą człowieka ku światu boskiemu, cnoty etyczne są niedoskona-

${ }^{24}$ Systema ethicae III libres, w: wydanie zbiorowe dzieł Keckermanna pt. Systema Systematum, t. II, Hanu 1613.

${ }^{25}$ Disputationes practicae [...] in Gymnasio Danriscano, Hanau 1602, także w: Systema Systematum, t. II, Hanau 1613.

${ }^{26}$ B. Nadolski, Życie i dziatalność uczonego gdańskiego Barttomieja Keckermanna. Studium z dziejów Odrodzenia na Pomorzu, Toruń 1961, s. 82.

${ }^{27}$ P. Szydłowski, Walka Bartłomieja Keckermanna (1572-1609) o niezależność etyki od teologii, Euhemer, „Przegląd Religioznawczy” nr 3, 1969, s. 70. 
łe i odnoszą się do świata ludzkiego. W praktykowaniu cnót duchowych biorą udział ludzie wierzący, w praktykowaniu zaś cnót etycznych mogą brać udział ludzie o różnych światopoglądach i wiarach, w przeszłości byli to choćby starożytni poganie. Podobnemu podziałowi podlegają również czyny w zależności od tego, czy za ich pośrednictwem człowiek wypełnia obowiązki wobec Boga, samego siebie czy bliźniego.

Bardzo cennym źródłem informacji do nauczaniu etyki w ówczesny Gimnasium Dantiscanum są Disputationes practicae, czyli szczegółowe sprawozdania z publicznych dysput. Odbywały się one pod kierunkiem Keckermanna i dotyczyły różnych dziedzin, w tym zagadnień etycznych. Znajdujemy tam między innymi siedem dysput na tematy etyczne. Na pierwszym miejscu ulokowano dysputy „O szczęśliwości społecznej, czyli moralnej i o cnocie w ogólności - problemów sześćn ${ }^{\prime \prime 2}$. Ale już na drugim miejscu znajdują się dysputy o roztropności i to w rekordowej ilości problemów - bo aż trzydzieści trzy. Fakt ten jest niewątpliwie świadectwem szczególnie żywego zainteresowania Keckermanna i jego uczniów problematyka roztropności, rangi, jaką cnocie tej nadawano i zrazem bogactwem podjętych na jej temat zagadnień. Wyszczególnienie na pierwszych miejscach problematyki szczęśliwości i roztropności jest świadectwem tego, że etyka gdańskiego filozofa łączyła problematykę szczęścia i roztropności, te dwie wartości godziła i widziała je w ścisłym związku, że nasycona ona była zarówno akcentami eudajmonistycznymi jak i tymi, które wiążą się z tematyką intelektualizmu etycznego.

Duch racjonalności $\mathrm{w}$ etyce uwidacznia się także $\mathrm{w}$ poglądach innego przedstawiciela myśli protestanckiej Jana Jonstona (1603-1675) wybitnego lekarza, przyrodnika, filozofa, historyka, pedagoga i filologa. Wśród jego rozlicznych zainteresowań pojawia się także tematyka etyczna. Rozważa ją głównie w rozprawie pt. Enchiridion ethicum (Podręcznik moralności). W katalogu podejmowanych przez Joinstona tematów z zakresu etyki ważne miejsce zajmuje zaproponowana klasyfikacja czynów moralnych.

$\mathrm{W}$ duchu arystotelesowskim ale i intelektualizmu etycznego Jonston dowodzi, że czyny moralnie pozytywne mają to do siebie, że spełniają wymóg umiarkowania i panuje nad nimi rozum. Towarzyszy im zawsze świadomość spełniania uczynków dobrych, spokój duszy, zadowolenie, poczucie godności, szacunek otoczenia i inne dodatnie odczucia. Czyny złe, nikczemne i niegodziwe mają miejsce tam, gdzie

\footnotetext{
${ }^{28}$ Tamże, s. 76.
} 
rozum i świadomość dobra wycofują się na skrajnie odległy plan bądź przestają mieć jakiekolwiek znaczenie i wpływ.

Jonston uważa, że praktykowanie cnót i ich imperatywnych odpowiedników wymaga znajomości mechanizmów rządzących naszymi naturalnymi skłonnościami. Ich rozpoznanie pozwala lepiej panować nad naszymi działaniami, dzięki nim wiemy, kiedy postępować zgodnie z naturalnymi skłonnościami, a kiedy należy im się przeciwstawić, aby nie wykroczyć „poza dozwolone granice”. Ważne jest także, aby we wszystkim postępować „roztropnie i przezornie”. Postępowania moralnie słuszne wymaga zaangażowania wiedzy, rozumu i właściwych rozeznań. Są one niezbędne, przy tak cenionej i zalecanej przez Jonstona postawie życiowej jaką jest zrównoważone usposobienie. To, zdaniem Jonstona, szczególnie cenna cecha charakterologiczna, posiadająca głęboki wymiar moralny. Człowiek zrównoważony w obliczu zarówno pomyślnych, jak i niepomyślnych przypadków i zrządzeń losu zachowuje wewnętrzną równowagę i nie popada w żadne skrajności - „w powodzeniu nie wynosi się, ani też nie upada na duchu wśród klęsk [...] zawsze spokojny i zdolny do działania nawet wśród bólu, nie zdradza żadnych oznak rozpaczy, mężnie znosi zło, którego uniknąć nie może, staje się twardy we wszystkich trudnościach"29.

Przywołajmy także postać Joachima Pastoriusa (1611-1681), którego zaliczyć należy do grona wybitnych przedstawicieli ówczesnego rodzimego życia intelektualnego, zasłużonego na polu historii, pedagogiki i wychowania młodzieży. Pastorius tworzył swą etykę w duchu epoki, opierając się na Arystotelesie, ale istotny wpływ wywarły na niego także idee socyniańskie. Wiele miejsca poświęca cnocie roztropności. Korzystając z cnoty roztropności, zyskujemy zdolność dokonywania właściwych, moralnie słusznych wyborów. Pozwala ona nadać naszemu życiu właściwy kierunek, w świat naszych emocji wprowadza umiar i podpowiada wskazania, dzięki którym człowiek „potrafi przystosować się do prądu czasu polityki, bez ujmy dla uczciwości"30.

Do niektórych idei intelektualizmu etyczne nawiązuje także myśli filozoficzno-społecznej przedstawiciela ruchu ariańskiego Jana Crella (1590-1633). Podejmuje on bogaty katalog zagadnień etycznych. Z punktu

${ }^{29}$ J. Jonston, Polymathiae philologicae, Frankfurt i Lipsk 1660; Encyklopedia pojęć etycznych, w: Filozofia i myśl społeczna XVII wieku, t. 2, oprac. Z. Ogonowski, Warszawa 1979, s. 104.

${ }^{30}$ K. Kubik, Joachim Pastorius - gdański pedagog CVII wieku, Gdański 1970, s. 127. 
widzenia naszych zainteresowań skupmy uwagę na zagadnieniu cnoty, któremu autor Prima ethices elementa poświęca stosunkowo dużo miejsca w swych rozważaniach. Cnotę definiuje jako „trwałą dyspozycję rozumnej duszy ludzkiej, doskonalącą człowieka i sprawiającą, że skutki jego działania są dobre" ${ }^{\prime \prime 31}$. Jest ona sprawnością, którą ludzie nabywają dzięki określonym staraniom i wysiłkom. W kolejności autor wyróżnia cnotę intelektu i cnotę obyczajów, co odpowiada arystotelesowskiemu podziałowi na cnoty dianoetyczne i cnoty etyczne. Powyższy podział uzasadnia to, że duszę rozumną, która jest podmiotem cnoty pojmować należy: „bądź jako rozumną samą w sobie, kiedy mianowicie mówimy o intelekcie, czyli umyśle; bądź jako rozumną w sposób akcydentalny, kiedy mianowicie mówimy o popędzie posłusznym rozumowi, z którym jest połączony w tym samym człowieku. Obie te władze duszy doskonalą się dzięki pewnym dyspozycjom właściwym człowiekowi. Dyspozycje te, nazywane cnotami, musimy rozróżniać, tak jak rozróżniamy podmioty"32.

Autor koncentruje również uwagę na przyczynach sprawczych cnoty jako źródłach wszystkich trwałych dyspozycji i wymienia trzy ich następujące rodzaje. Natura, nauka i ćwiczenia. Nie analizuje natomiast przyczyn religijnych cnoty, gdyż te są przedmiotem zainteresowań teologii. Rola natury w nabywaniu cnoty ma dwojaki wymiar. To właśnie natura daje nam zdolność osiągania cnoty, a także określone skłonności i bodźce, które są jakby uzupełnieniem owej naturalnej skłonności. Istotną rolę w nabywaniu cnoty - twierdzi Crell - spełnia nauka. Dostarcza ona ważnych wskazówek, podpowiada nam, ku czemu należy dążyć albo czego unikać, czym jest dobro - o tym właśnie stara się mówić etyka jako odrębna nauka. Ponadto nauka ukazuje te dyspozycje i przedmioty, które skłaniają do nabywania cnoty. Bezpośrednim sojusznikiem nauki są ćwiczenia. Nie wystarczy wiedzieć, czym jest dobro i zło, jakie są nasze powinności, należy tę wiedzę ugruntować w trwałych dyspozycjach, co jest zdaniem ćwiczeń. Każde bowiem trwałe nabywanie cnoty poprzedzone powinno być praktycznymi działaniami, wytrwałym ćwiczeniem. Owe zaś ćwiczenia przebiegać powinny w myśl określonych wskazówek i reguł.

Kolejny wątek wpisujący się $\mathrm{w}$ ideę intelektualizmu etycznego napotykamy w traktacie Etyka Aristotelica, w którym Crell wypowiada się na temat woli, wolności woli, czynu dobrowolnego oraz czynów do-

\footnotetext{
${ }^{31}$ Tamże.

${ }^{32}$ Tamże.
} 
konywanych w wyniku świadomego wyboru. Te ostatnie odróżnia od czynów dobrowolnych, które dokonywane są najczęściej pod wpływem emocji, pożądań i zmysłów to, że są skutkiem świadomego wyboru i odwoływania się do władzy rozumu. A czyny, wynikając z świadomego namysłu, Crell ceni bardzo wysoko. Także naturę woli najtrafniej - zdaniem myśliciela - wyjaśnia pogląd, „że jest to władza dążąca do tego, co rozum uzna za dobre, oraz unikając tego, co uzna za złe"33. Crell analizuje różnego rodzaju zależności, jakie pojawiają się między rozumem, wolą i pożądaniem. Pisze o walce, jaką toczą ze sobą rozum i pożądaniem oraz roli, jaką w tej rywalizacji przypada pełnić woli. Podkreśla znaczenie wolności woli, ale jednocześnie dodaje, że wolna wola tylko w sojuszu z rozumnością przynosi jednostce i zbiorowości dodatnie skutki.

Wiele idei bliskich intelektualizmowi etycznemu odnajdujemy również w poglądach innego reprezentanta ruchu ariańskiego Andrzeja Wiszowatego (1608-1678). W rozprawie Bodźce cnót, wędzidła grzechu Wiszowaty akcentuje związek wiedzy i moralności. Dowodził, że brak należytego rozpoznania tego, co dobre i cnotliwe prowadzi niechybnie na drogę zła. „Niewiedza i nieznajomość rzeczy godnych tego, by były znane, jak również zaślepienie i brak zastanowienia się - powie pisarz - stają się dla wielu ludzi przyczyną złego postępowania, zaniedbywania cnót oraz popełniania grzechów”. Dlatego - twierdzi - „do zdobycia cnoty potrzebna jest mądrość", to jest "stałe usposobienie umysłu, skłaniające do tego, by o rzeczach, jakimi one są, a więc prawdziwie poznanych, wydawać słuszny sąd stosownie do tego, jak są one godne"34. Proces poznawania człowiek powinien zaczynać od samego siebie, uświadamiając sobie "godność swej natury". Jeśli już posiadł zdolność rozumienia tego, co prawdziwe, to pragnie tego, co dobre, a następnie tego, „co niebiańskie i boskie" ${ }^{35}$. Ale powinien również mieć na względzie swoją „niegodność i nędzę”, i to, że tak bardzo oddalony jest od Boga. W człowieku nieustannie toczy się walka między niższą jego częścią tj. cielesnością, namiętnościami i pożądaniami, a więc tym, co ciągnie go do tego, co ziemskie i grzeszne a "zdrowym” rozumem”, który kieruje go na drogę cnoty. Wiedza o naturze człowieka jest niezbędna do tego, aby

${ }^{33}$ J. Crell, Ethica Aristotelica, w: Myśl ariańska w Polsce XVII wieku. Antologia tekstów, oprac. Z. Ogonowski, Warszawa 1991, s. 558.

${ }^{34}$ A. Wiszowaty, Stimuli Virtutum, w: Bodźce cnót, wędzidła grzechów, w: Myśl ariańska w Polsce XVII wieku. Antologia tekstów, s. 601.

${ }^{35}$ Tamże, s. 602. 
każdy z nas zdawał sobie sprawę z tego, do jakiego grzechu jest skłonny i w oparciu o tę wiedzę szukał sposobów przeciwstawienia się owemu „Wrogowi wewnętrznemu" ${ }^{\prime 36}$. Refleksja nad cnotą każe nam zastanowić się nad naturą tego, co jest jej przeciwieństwem - to jest „wadą moralną" i grzechem. Pojawiają się one w życiu człowieka wówczas, gdy namiętności, a nie rozum nad nimi panują, gdy staje się ich "sługą i niewolnikiem”, [...] "głupcem podobnym do nierozumnych zwierząt" ${ }^{\prime 37}$. Zauważmy, że u Wiszowatego pojawia się myśl o wyraźnie sokratejskiej proweniencji, że zło jest efektem niewiedzy i głupoty, i zjawia się wtedy, gdy dokonuje się "odstępstwo i zboczenie od zdrowego rozumu"38. Grzech przynosi jedynie krótkotrwałą rozkosz, i gdy „miną kuszące swym urokiem fałszywe przyjemności", wówczas powraca rozum, a wraz z nim odzywa się sumienie - ów "głos ducha” [...] „piętnujący i karzący człowieka z racji popełnionych przez niego przestępstw" ${ }^{\prime \prime 39}$. Dręczący człowieka wyrzut sumienia pojawia się wtedy, gdy do głosu dochodzi rozum, który zdając sobie sprawę z dokonanego zła, staje się prawdziwym "oskarżycielem, świadkiem, sędzią, a nawet katem"40. Fenomen sumienia wyjaśnia Wiszowaty poprzez odwołanie się do uzasadnień racjonalistycznych. Sumienie staje się tu głosem rozumu, który odzyskując panowanie nad sytuacją, jakby formułuje ocenę tego, co się już dokonało, i wymierza stosowną do czynów sankcję, która ma charakter wewnętrzny i występuje w postaci wyrzutów sumienia.

Etyka Wiszowatego jest etyką eudajmonistyczną, gdyż cel życia ludzkiego upatruje w osiągnięciu szczęścia i głosi, że dążenie do szczęścia jest głównym motywem działania ludzkiego. Jest również etyką zorientowaną perfekcjonistycznie, gdyż podnosi wysoko poprzeczkę wymagań i podkreśla mocno znaczenie pracy, wysiłku i trudu w osiąganiu dobra najwyższego. Jest także etyka racjonalistyczną. Wyraźnie waloryzuję rozum $\mathrm{w}$ ocenie i działaniu etycznym, stawia go przed sferą namiętności i uczuć. Zaleca postępowanie zgodne ze wskazaniami rozumu, który najlepiej potrafi rozpoznać obszary dobra i zła moralnego. Te właściwości myśli etycznej Wiszowatego dobrze dokumentują wcześniej wyrażony pogląd, że wiele jej idei inspirowanych jest przesłaniem intelektualizmu etycznego.

\footnotetext{
36 Tamże, s. 603.

37 Tamże, s. 609.

38 Tamże.

39 Tamże, s. 610.

40 Tamże.
} 
$* * *$

W słowie podsumowującym powyższe rozważania należy jeszcze raz przypomnieć, że staropolska myśl etyczna epoki znajdowała się pod przemożnym wpływem arystotelizmu. Nie oznacza to, że poszczególni myśliciele i pisarze zawsze niewolniczo trzymali się spuścizny Stagiryty. $Z$ reguły przyznając się do tego, że rodowód swoich poglądów czerpią z jego myśli, przywoływali także idee o innej proweniencji. Zadaniem niniejszego artykułu było uwypuklenia tych myśli w poglądach etycznych XVI i XVII wieku, które w różnym zakresie nawiązywały do idei wnoszonych przez sokratejski intelektualizm etyczny, który akcentuje związek wiedzy i moralności, mądrości i cnotliwości, rozumu i etyczności. Okazuje się, że wielu autorów świadomie do tego sposobu myślenia nawiązywało, podkreślając rolę owych sojuszy. Można więc stwierdzić, że intelektualizm jest wyraźnie zaznaczającą się cechą staropolskiej myśli etycznej. Wprawdzie nie zawsze był tak samo rozumiany i nie zawsze wpisywał się, kanoniczny schemat raczej był różnie modyfikowany i interpretowany. Niewątpliwie dominował pogląd, że cnota i dociekania na temat cnoty są rezultatem rozumnych rozważań na temat dobra. Podkreślano, że już samo nabywanie cnoty wymaga zaangażowania intelektu, a proces osiągania cnoty dokonuje się $\mathrm{w}$ miarę rozwoju intelektualnego. Dowodzono, że osoba o ukształtowanych cnotach posiada dyspozycje intelektualne, jak rozwagę i roztropność, dzięki którym może wydawać właściwe sądy i podejmować poprawne decyzje. Wskazywano, że warunkiem dokonywania słusznych ocen i wartościowań etycznych jest właściwe rozpoznanie rozumowe dobra i zła. Ale też zastanawiano się nad rolą rozumu i woli w postępowaniu etycznym człowieka. Wskazywano na związek wiedzy i woli charakteru i mądrości, również mądrości i szczęśliwości.

Powszechnie akceptowano pogląd, że mądrość, rozumność nie są czymś danym, nie rodzimy się z nimi, lecz je nabywamy. Taki zaś pogląd zachęcał do refleksji na temat nabywania tych wartości. Rozumność i roztropność to wartości, które ludzie nabywają dzięki świadomym staraniom i wysiłkom, stąd wskazywano na znaczenie edukacji etycznej. Modrość zaś, jako nieodłączny warunek etyczności, jest pojęciem znacznie szerszym, mieści w sobie rozumność i roztropność, ale jest również owocem wielu doświadczeń życiowych umiejętnie w sferze intelektualnej przetrawionych i spożytkowanych. 


\section{ETHICAL INTELLECTUALISM IN OLD POLISH MORAL THINKING}

\section{SUMMARY}

The task of the present article is to present those thoughts in the ideas of polish ethical writers of XVI and XVII century, who refer to, although to a different extent, to the Socratic idea of ethical intellectualism. In the light of conducted studies, the intellectualism should be considered as one of the most distinct features of the Old Polish ethical thought. An explicit acceptance of the idea of a close relationship between the knowledge and morality, wisdom and virtue, reason and ethics is noticeable in writings of many thinkers of that period. Sometimes the ethical intellectualism occurred in a relatively truthful form, otherwise, it was modified on various ways. However, its basic sense was accepted by polish writers of this epoch. It was mentioned for example that the acquisition of virtue itself, requires the engagement of the intellect on the other hand, the accomplishment of virtue proceeds in conjunction with the intellectual development. It has being proven that the person of the firm virtues is equipped with intellectual dispositions with, especially highly appreciated, prudence and sagacity, which allow for correct judgements and decisions. It was underlined that the correct intellectual discrimination between the good and the bad is a prerequisite for making right moral appraisals. It was pronounced for a broad ethical education resting on rational premises. 